\title{
Pengaruh Proporsi Mikrosilika Dan Kandungan Lumpur Terhadap Kuat Tekan Mortar
}

\author{
Pradipta Rendy Mahesa Dananjaya ${ }^{1}$, Aditya Angga Herdiawan ${ }^{2}$ \\ email: ${ }^{2}$ adityaanggaherdiawan41@gmail.com \\ Program Studi Teknik Sipil, Fakultas Teknik, Unika Soegijapranata, Semarang, Universitas Katolik \\ Soegijapranata; Jl. Pawiyatan Luhur IV/1 Bendan Dhuwur Semarang 50234, 024-8441555
}

\begin{abstract}
Abstrak
Mikrosilika adalah limbah atau produk sampingan dari pembuatan logam silikon atau paduan silikon. Mikrosilika yang dicampur dalam mortar atau campuran beton dapat mengurangi porositas mortar. Penggunaan mikrosilika juga dapat meningkatkan daya rekat antara pasta semen dan agregat. Meningkatnya daya rekat antara pasta semen dan agregat akan meningkatkan kuat tekan mortar. Salah satu bahan mortar adalah pasir. Beberapa jenis pasir seringkali mengandung kadar lumpur yang tinggi. Lumpur dalam mortar atau campuran beton dapat mencegah adhesi yang kuat antara butiran pasir dan pasta semen. Berkurangnya daya rekat antara butiran pasir dan pasta semen berdampak pada penurunan kuat tekan mortar sehingga kualitas mortar yang direncanakan tidak tercapai. Pengujian yang dilakukan pada penelitian ini adalah uji kuat tekan mortar dengan sampel mortar dengan ukuran $5 \mathrm{~cm} \times 5 \mathrm{~cm} \times 5 \mathrm{~cm}$. Mikrosilika menggantikan 5\%,10\%, 15\%, 20\%, 25\% dan 30\% dari berat pasir dan penambahan lumpur adalah $10 \%$ dari berat pasir. Setiap komposisi terdiri dari 3 sampel sehingga jumlah sampel adalah 84. Penelitian ini bertujuan untuk mengetahui pengaruh penggantian mikrosilika dan penambahan lumpur terhadap kuat tekan mortar umur 7 hari dan 28 hari. Tujuan lain dari penelitian ini adalah untuk menentukan rasio penggantian mikrosilika dan kandungan lumpur yang optimal terhadap kuat tekan mortar.
\end{abstract}

Kata kunci : mortar, limbah, mikrosilika, dan kuat tekan mortar

\begin{abstract}
Microsilica is the waste or byproduct of the manufacture of silicon metal or silicon alloy. Microsilica mixed in a mortar or concrete mixture can reduce the porosity of the mortar. The use of microsilica can also increase the adhesion between cement paste and aggregate. The increased adhesion between cement paste and aggregate will increase compressive strength of mortar. One of mortar's materials is sand. Several types of sand often contain high levels of mud. The mud in mortar or concrete mixture can prevent strong adhesion between sand grains and cement paste. The reduced adhesion between sand grains and cement paste has an impact on decreasing mortar compressive strength so that planned quality of mortar is not achieved. The test carried out in this study is a mortar compressive strength test with mortar samples with $5 \mathrm{~cm} \times 5 \mathrm{~cm} \times 5 \mathrm{~cm}$ size. Microsilica replace $5 \%, 10 \%, 15 \%$, $20 \%, 25 \%$ and $30 \%$ of sand's weight and the addition of mud is $10 \%$ of sand's weight. Each composition consists of 3 samples so that the total number of the samples is 84. This study aims to determine the effect of replacing microsilica and adding mud to the compressive strength of mortar aged 7 days and 28 days. Another objective of this research is to determine the optimal ratio of replacement of microsilica and mud content to the compressive strength of mortar.
\end{abstract}

Keywords: mortar, waste, microsilica, and mortar compressive strenght 


\section{PENDAhuluan}

Menurut SNI 03-6825-2002, menyatakan bahwa mortar didefinisikan sebagai campuran material yang terdiri dari agregat halus berupa pasir dan bahan perekat berupa Portland Cement ditambah air dengan komposisi tertentu. Mortar merupakan material yang sering digunakan di bidang konstruksi. Mortar paling sering digunakan sebagai perekat keramik, bata ringan, plester dinding, dan acian. Bahan penyusun mortar sering dimodifikasi dengan cara penambahan bahan tambah tertentu. Modifikasi mortar juga dapat dilakukan dengan cara subtitusi atau penggantian bahan penyusunnya dengan bahan yang lain, baik sebagian maupun keseluruhan. Modifikasi bahan penyusun mortar diharapkan dapat menambah sifat tertentu pada mortar, misalnya lebih cepat mengeras, lebih encer sehingga tingkat workability meningkat tanpa mengurangi mutu mortar dan meningkatkan kuat tekan.

Salah satu bahan yang digunakan untuk memodifikasi mortar adalah mikrosilika atau yang dikenal juga dengan silica fume. Mikrosilika merupakan sisa atau hasil sampingan dari pembuatan silicon metal atau silicon alloy. Menurut "Spesification for Silica Fume for Use in Hydraulic Cement Concrete and Mortar" (ASTM.C.1240,1995:637-642),

mikrosilika merupakan material pozzolan yang halus.

Berdasarkan penelitian yang dilakukan oleh Mahyar (2012), didapatkan bahwa mikrosilika yang dicampurkan dalam campuran beton atau mortar dapat mengurangi porositas mortar yang merupakan perbandingan volume poripori mortar terhadap volume total mortar. Penggunaan mikrosilika juga dapat meningkatkan daya rekat antara pasta semen dengan agregat. Meningkatnya daya rekat antara pasta semen dengan agregat akan meningkatkan kuat tekan mortar.

Pemanfaatan mikrosilika sebagai bahan pengganti sebagian pasir dalam campuran mortar juga dapat membantu mengurangi jumlah limbah mikrosilika. Mengingat mikrosilika merupakan biproduk atau produk sampingan dari pembuatan silicon alloy dan pemanfaatannya masih kurang maksimal.

Berdasarkan penelitian yang dilakukan oleh Sari, Anif dan Mizwar (2019) yang melakukan penelitian dengan menambahkan mikrosilika dengan semen terhadap nilai kuat tekan beton mutu tinggi dengan kadar 5\%, 10\%, 15\%, dan 30\% dari berat semen. Berdasarkan hasil penelitian yang dilakukan, didapatkan bahwa penambahan mikrosilika pada beton mutu tinggi dapat meningkatkan kuat tekan beton. Peningkatan kuat tekan beton terjadi hingga penambahan mikrosilika sebesar $15 \%$, selebihnya pada penambahan mikrosilika lebih dari $15 \%$ kuat tekan beton akan menurun.

\begin{tabular}{lcr}
\multicolumn{2}{c}{ Berdasarkan penelitian } & yang \\
dilakukan oleh & Mahyar & $(2013)$, \\
melakukan penelitian & dengan \\
menambahkan & mikrosilika & dalam
\end{tabular}
campuran beton untuk meningkatkan kuat tekan beton normal dengan kadar mikrosilika 0\%, 5\%, 10\%, 15\%, dan 20\%. Berdasarkan hasil penelitian yang dilakukan, didapatkan bahwa penambahan mikrosilika pada beton dapat meningkatkan kuat tekan beton. Peningkatan kuat tekan beton terjadi hingga penambahan mikrosilika sebesar $15 \%$. Penambahan mikrosilika dengan kadar 20\% tidak memberikan hasil yang optimal dan terjadi penurunan kuat tekan beton.

Salah satu bahan penyusun mortar adalah pasir. Beberapa jenis pasir sering 
memiliki kadar lumpur yang cukup tinggi. Menurut Zulfikar dan Priyanto (2019), menyatakan bahwa lumpur pada campuran mortar dapat menghalangi terjadinya lekatan yang kuat antara butiran pasir dengan pasta semen. Berkurangnya daya lekat antara butiran pasir dengan pasta semen berdampak pada penurunan kuat tekan mortar sehingga mutu mortar yang direncanakan tidak tercapai.

Berdasarkan uraian tersebut, penelitian yang berjudul "Pengaruh Proporsi Mikrosilika dan Kandungan Lumpur Terhadap Kuat Tekan Mortar" bertujuan untuk mengkaji peningkatan atau penurunan kuat tekan mortar akibat pemanfaatan mikrosilika dan adanya lumpur pada agregat halus berupa pasir.

\section{METODE PENELITIAN}

Penelitian ini dilakukan untuk mengetahui dan mendapatkan kuat tekan optimal mikrosilika dan kandungan lumpur terhadap kuat tekan mortar. Manfaat dari penelitian ini dilakukan untuk membantu mengurangi jumlah limbah mikrosilika dengan cara dimanfaatkan sebagai bahan pengganti dalam campuran pembuatan mortar dan mendapat mortar dengan kuat tekan yang lebih baik dengan pemanfaatan limbah mikrosilika. Pengujian yang dilakukan pada penelitian ini adalah pengujian kuat tekan mortar dengan benda uji mortar dengan ukuran sisi $5 \mathrm{~cm} \times 5 \mathrm{~cm} \times 5 \mathrm{~cm}$. Penggantian mikrosilika sebesar 5\%, 10\%, $15 \%, 20 \%, 25 \%$ dan $30 \%$ dari berat pasir dan penambahan lumpur sebesar $10 \%$ dari berat pasir. Setiap komposisi berjumlah 3 buah benda uji sehingga jumlah total benda uji berjumah 84 buah. Penelitian ini bertujuan untuk mengetahui pengaruh penggantian mikrosilika dan penambahan lumpur terhadap kuat tekan mortar umur 7 hari dan 28 hari.

\section{HASIL DAN PEMBAHASAN Hasil Pengujian Kuat Tekan Mortar}

Pengujian kuat tekan mortar dilakukan pada umur mortar 7 dan 28 hari. Tata cara pengujian kuat tekan mortar berdasarkan SNI 03-6825-2002. Pengujian kuat tekan mortar dilakukan dengan menggunakan compression testing machine yang tersedia di Laboratorium Bahan Bangunan Universitas Katolik Soegijapranata. Compression testing machine yang digunakan dapat memberikan hasil nilai kuat tekan mortar secara langsung dalam satuan kilo newton $(\mathrm{kN})$.

\section{Langkah-langkah pengujian kuat tekan mortar}

Pengujian kuat tekan mortar dilakukan setelah proses curing selesai dan benda uji mortar telah mencapai umur yang direncanakan yaitu 7 dan 28 hari. Sebelum pengujian dilakukan, benda uji mortar diambil dari bak perendaman pada umur 6 hari dan 27 hari untuk proses pengeringan selama 24 jam. Pengeringan dilakukan dengan cara diangin-anginkan. Benda uji mortar juga harus dipastikan bersih dari kotoran-kotoran yang menempel.

Uji kuat tekan bertujuan untuk mengetahui kemampuan dari benda uji tersebut menahan gaya tekan. Uji kuat tekan dilakukan di Laboratorium Bahan Bangunan Teknik Sipil Fakultas Teknik Universitas Katolik Soegijapranata. Langkah-langkah pengujian kuat tekan mortar diperlihatkan pada Lampiran P. Berdasarkan hasil pengujian kuat tekan mortar didapatkan: 
Tabel 1. Hasil Uji Kuat Tekan Mortar Umur 7 Hari

\begin{tabular}{|c|c|c|c|c|c|c|}
\hline \multirow[t]{2}{*}{$\begin{array}{c}\text { No. } \\
\text { Kompo } \\
\text { sisi }\end{array}$} & \multirow[t]{2}{*}{$\begin{array}{c}\text { Kadar } \\
\text { Mikrosilika } \\
\text { (\%) }\end{array}$} & \multirow[t]{2}{*}{$\begin{array}{c}\text { Kadar } \\
\text { Lumpur } \\
(\%)\end{array}$} & \multicolumn{3}{|c|}{$\begin{array}{c}\text { Has il Uji } \\
\text { Kuat Tekan } \\
(\mathrm{kN})\end{array}$} & \multirow{2}{*}{$\begin{array}{c}\text { Rata-rata } \\
\text { Hasil Uji } \\
\text { Kuat Tekan } \\
\quad(\mathrm{kN})\end{array}$} \\
\hline & & & 1 & 2 & 3 & \\
\hline 1 & 0 & 0 & 16,5 & 17,5 & 18 & 17,33 \\
\hline 2 & 0 & 10 & 17 & 16,5 & 17,5 & 17,00 \\
\hline 3 & 5 & 0 & 21,5 & 19 & 20 & 20,17 \\
\hline 4 & 5 & 10 & 19 & 20 & 21,5 & 20,17 \\
\hline 5 & 10 & 0 & 18 & 20 & 19 & 19,00 \\
\hline 6 & 10 & 10 & 19 & 19 & 18,5 & 18,83 \\
\hline 7 & 15 & 0 & 30 & 20 & 30 & 26,67 \\
\hline 8 & 15 & 10 & 22 & 30 & 28 & 26,67 \\
\hline 9 & 20 & 0 & 20 & 22 & 22 & 21,33 \\
\hline 10 & 20 & 10 & 22 & 25 & 25 & 24,00 \\
\hline 11 & 25 & 0 & 27 & 20 & 20 & 22,33 \\
\hline 12 & 25 & 10 & 22 & 22 & 28 & 24,00 \\
\hline 13 & 30 & 0 & 22 & 20 & 18 & 20,00 \\
\hline 14 & 30 & 10 & 22 & 20 & 22 & 21,33 \\
\hline
\end{tabular}

Tabel 2. Hasil Uji Kuat Tekan Mortar Umur 28 Hari

\begin{tabular}{|c|c|c|c|c|c|c|}
\hline \multirow{2}{*}{$\begin{array}{c}\text { No. } \\
\text { Kompo } \\
\text { sisi }\end{array}$} & $\begin{array}{c}\text { Kadar } \\
\text { Mikrosilika } \\
(\%)\end{array}$ & $\begin{array}{c}\text { Kadar } \\
\text { Lumpur } \\
(\%)\end{array}$ & \multicolumn{3}{|c|}{$\begin{array}{c}\text { Hasil Uji } \\
\text { Kuat Tekan }\end{array}$} & $\begin{array}{c}\text { Rata-rata } \\
\text { Hasil Uji } \\
\text { Kuat Tekan } \\
(\mathrm{KN})\end{array}$ \\
\cline { 4 - 6 } & & 0 & 60,0 & 58,0 & 58,0 & 58,67 \\
\hline 1 & 0 & 10 & 62,0 & 60,0 & 60,0 & 60,67 \\
\hline 2 & 0 & 0 & 70,0 & 62,0 & 65,0 & 65,67 \\
\hline 3 & 5 & 10 & 68,0 & 68,0 & 70,0 & 68,67 \\
\hline 4 & 5 & 0 & 65,0 & 68,0 & 62,0 & 65,00 \\
\hline 5 & 10 & 10 & 70,0 & 62,0 & 60,0 & 64,00 \\
\hline 6 & 10 & 0 & 82,0 & 80,0 & 85,0 & 82,33 \\
\hline 7 & 15 & 10 & 80,0 & 82,0 & 82,0 & 81,33 \\
\hline 8 & 15 & 0 & 72,0 & 75,0 & 72,0 & 73,00 \\
\hline 9 & 20 & 10 & 75,0 & 72,0 & 78,0 & 75,00 \\
\hline 10 & 20 & 0 & 75,0 & 72,0 & 70,0 & 72,33 \\
\hline 11 & 25 & 10 & 70,0 & 70,0 & 75,0 & 71,67 \\
\hline 12 & 25 & 10 & 70,0 & 68,0 & 62,0 & 66,67 \\
\hline 13 & 30 & 0 & 65,0 & 62,0 & 70,0 & 65,67 \\
\hline 14 & 30 & 10 & & & \\
\hline
\end{tabular}

\section{Berat isi benda uji mortar}

Perhitungan berat isi mortar bertujuan untuk mengetahui berat mortar per satuan volume. Berat isi mortar dapat dihitung dengan rumus sebagai berikut:

$$
\gamma_{\mathrm{m}}=\frac{\mathrm{Bm}}{\mathrm{V}}
$$

Keterangan:

$\gamma_{\mathrm{m}}=$ berat isi mortar $(\mathrm{gr} / \mathrm{cm} 3)$

$\mathrm{Bm} \quad=$ berat benda uji (gr)

$\mathrm{V} \quad=$ volume benda uji $(\mathrm{cm} 3)$
Tabel 3. Berat dan Berat Isi Benda Uji Mortar Umur 7 Hari

\begin{tabular}{|c|c|c|c|c|c|c|c|c|c|c|}
\hline \multirow[t]{2}{*}{$\begin{array}{c}\text { No. } \\
\text { Kompo } \\
\text { sisi }\end{array}$} & \multirow[t]{2}{*}{$\begin{array}{c}\text { Kadar } \\
\text { Mikrosilika } \\
(\%)\end{array}$} & \multirow[t]{2}{*}{$\begin{array}{c}\text { Kadar } \\
\text { Lumpur } \\
(\%)\end{array}$} & \multicolumn{3}{|c|}{$\begin{array}{c}\text { Berat } \\
\text { Benda Uji } \\
\text { (gram) }\end{array}$} & \multirow{2}{*}{$\begin{array}{c}\text { Rata-rata } \\
\text { Berat } \\
\text { Benda Uji } \\
\text { (gram) }\end{array}$} & \multicolumn{3}{|c|}{$\begin{array}{c}\text { Berat Isi } \\
\text { Mortar } \\
\left(\text { gram } / \mathrm{cm}^{3}\right)\end{array}$} & \multirow{2}{*}{$\begin{array}{l}\text { Rata-rata } \\
\text { Berat } \\
\text { Isi Mortar } \\
\left(\mathrm{gram} / \mathrm{cm}^{3}\right)\end{array}$} \\
\hline & & & 1 & 2 & 3 & & 1 & 2 & 3 & \\
\hline 1 & 0 & 0 & 262 & 279,5 & 271 & 270,83 & 2,10 & 2,24 & 2,17 & 2,17 \\
\hline 2 & 0 & 10 & 284 & 285 & 276,5 & 281,83 & 2,27 & 2,28 & 2,21 & 2,25 \\
\hline 3 & 5 & 0 & 272 & 274,5 & 271 & 272,50 & 2,18 & 2,20 & 2,17 & 2,18 \\
\hline 4 & 5 & 10 & \begin{tabular}{|l|}
277,5 \\
\end{tabular} & 281 & 277 & 278,50 & 2,22 & 2,25 & 2,22 & 2,23 \\
\hline 5 & 10 & 0 & 270,5 & 272 & 269 & 270,50 & 2,16 & 2,18 & 2,15 & 2,16 \\
\hline 6 & 10 & 10 & 266,5 & 268,5 & 266,5 & 267,17 & 2,13 & 2,15 & 2,13 & 2,14 \\
\hline 7 & 15 & 0 & 249,5 & 249,5 & 253,5 & 250,83 & 2,00 & 2,00 & 2,03 & 2,01 \\
\hline 8 & 15 & 10 & 251 & 247 & 253,5 & 250,50 & 2,01 & 1,98 & 2,03 & 2,00 \\
\hline 9 & 20 & 0 & 242,5 & 245 & 240 & 242,50 & 1,94 & 1,96 & 1,92 & 1,94 \\
\hline 10 & 20 & 10 & 245,5 & 241,5 & 244 & 243,67 & 1,96 & 1,93 & 1,95 & 1,95 \\
\hline 11 & 25 & 0 & 237 & 229,5 & 227 & 231,17 & 1,90 & 1,84 & 1,82 & 1,85 \\
\hline 12 & 25 & 10 & 225,5 & 235 & 236 & 232,17 & 1,80 & 1,88 & 1,89 & 1,86 \\
\hline 13 & 30 & 0 & 229,5 & 227,5 & 222,5 & 226,50 & 1,84 & 1,82 & 1,78 & 1,81 \\
\hline 14 & 30 & 10 & 236 & 235,5 & 233,5 & 235,00 & 1,89 & 1,88 & 1,87 & 1,88 \\
\hline
\end{tabular}

Tabel 4. Berat dan Berat Isi Benda Uji Mortar Umur 28 Hari

\begin{tabular}{|c|c|c|c|c|c|c|c|c|c|c|}
\hline \multirow[t]{2}{*}{$\begin{array}{c}\text { No. } \\
\text { Kompo } \\
\text { sisi }\end{array}$} & \multirow[t]{2}{*}{$\begin{array}{c}\text { Kadar } \\
\text { Mikrosilika } \\
(\%)\end{array}$} & \multirow[t]{2}{*}{$\begin{array}{c}\text { Kadar } \\
\text { Lumpur } \\
(\%)\end{array}$} & \multicolumn{3}{|c|}{$\begin{array}{c}\text { Berat } \\
\text { Benda Uji } \\
\text { (gram) }\end{array}$} & \multirow{2}{*}{\begin{tabular}{|c|} 
Rata-rata \\
Berat \\
Benda Uji \\
(gram)
\end{tabular}} & \multicolumn{3}{|c|}{$\begin{array}{c}\text { Berat Isi } \\
\text { Mortar } \\
\left(\mathrm{gram} / \mathrm{cm}^{3}\right)\end{array}$} & \multirow{2}{*}{\begin{tabular}{|c|}
$\begin{array}{c}\text { Rerata } \\
\text { Berat } \\
\text { Isi Mortar } \\
\left(\mathrm{gram} / \mathrm{cm}^{3}\right)\end{array}$ \\
\end{tabular}} \\
\hline & & & 1 & 2 & 3 & & 1 & 2 & 3 & \\
\hline 1 & 0 & 0 & 268,5 & 268 & 265,5 & 267,33 & 2,15 & 2,14 & 2,12 & 2,14 \\
\hline 2 & 0 & 10 & 293 & 294,5 & 296,5 & 294,67 & 2,34 & 2,36 & 2,37 & 2,36 \\
\hline 3 & 5 & 0 & 275 & 271,5 & 271 & 272,50 & 2,20 & 2,17 & 2,17 & 2,18 \\
\hline 4 & 5 & 10 & \begin{tabular}{|l|l|}
287 \\
\end{tabular} & 284 & 283,5 & 284,83 & 2,30 & 2,27 & \begin{tabular}{|l|}
2,27 \\
\end{tabular} & 2,28 \\
\hline 5 & 10 & 0 & 272,5 & 273 & 271,5 & 272,33 & 2,18 & 2,18 & 2,17 & 2,18 \\
\hline 6 & 10 & 10 & \begin{tabular}{|l|}
263 \\
\end{tabular} & \begin{tabular}{|l|}
264,5 \\
\end{tabular} & 267,5 & 265,00 & 2,10 & 2,12 & 2,14 & 2,12 \\
\hline 7 & 15 & 0 & \begin{tabular}{|l|}
264 \\
\end{tabular} & 263,5 & 265 & 264,17 & 2,11 & 2,11 & 2,12 & 2,11 \\
\hline 8 & 15 & 10 & \begin{tabular}{|l|l|}
261 \\
\end{tabular} & 268 & 266,5 & 265,17 & 2,09 & 2,14 & 2,13 & 2,12 \\
\hline 9 & 20 & 0 & 247 & 253 & 250 & 250,00 & 1,98 & 2,02 & 2,00 & 2,00 \\
\hline 10 & 20 & 10 & 259,5 & 258 & \begin{tabular}{|l|}
259 \\
\end{tabular} & 258,83 & 2,08 & 2,06 & 2,07 & 2,07 \\
\hline 11 & 25 & 0 & 241,5 & 240,5 & 239 & 240,33 & 1,93 & 1,92 & 1,91 & 1,92 \\
\hline 12 & 25 & 10 & 249,5 & 253,5 & 251 & 251,33 & 2,00 & 2,03 & 2,01 & 2,01 \\
\hline 13 & 30 & 0 & 232 & 230 & \begin{tabular}{|l|}
229 \\
\end{tabular} & 230,33 & 1,86 & \begin{tabular}{|l|}
1,84 \\
\end{tabular} & \begin{tabular}{|l|}
1,83 \\
\end{tabular} & 1,84 \\
\hline 14 & 30 & 10 & 231,5 & 234 & 234,5 & 233,33 & 1,85 & 1,87 & \begin{tabular}{|l|}
1,88 \\
\end{tabular} & 1,87 \\
\hline
\end{tabular}

\section{Perhitungan kuat tekan mortar}

Pengujian kuat tekan mortar yang dilakukan dengan menggunakan alat uji kuat tekan (compression testing machine) menghasilkan gaya tekan maksimum saat mortar mengalami retak atau pecah. Pengujian kuat tekan benda uji mortar compression testing machine menghasilkan kuat tekan mortar dalam satuan kN. Menurut SNI 03-6825-2002, untuk mengitung kuat tekan benda uji mortar dengan satuan MPa dapat dihitung menggunakan rumus:

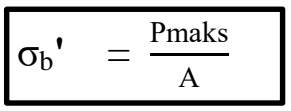

Keterangan:

$\sigma b^{\prime} \quad=$ Kuat tekan benda uji mortar (MPa) 
Pmaks = Gaya tekan maksimum $(\mathrm{N})$

A $\quad=$ Luas permukaan benda uji mortar $\left(\mathrm{mm}^{2}\right)$

Pada penelitian ini, alat uji kuat tekan (compression testing machine) yang digunakan menghasilkan gaya tekan maksimum dalam satuan kN. Sehingga untuk mendapatkan gaya tekan maksimum dalam satuan $\mathrm{N}$, gaya tekan maksimum dikalikan dengan 1000.

Sehingga didapatkan rumus kuat tekan benda uji mortar umur 7 hari sebagai berikut:

$\sigma_{\mathrm{b}}{ }^{\prime}=\frac{\text { Pmaks } \times 1000}{\mathrm{~A}}$

Keterangan:

$\sigma_{\mathrm{b}}{ }^{\prime}=$ Kuat tekan benda uji mortar (MPa)

Pmaks = Gaya tekan maksimum $(\mathrm{kN})$

$\mathrm{A} \quad=$ Luas permukaan benda uji $\operatorname{mortar}\left(\mathrm{mm}^{2}\right)$

Perhitungan luas penampang benda uji mortar:

$$
\begin{aligned}
\mathrm{A} & =\mathrm{s} \times \mathrm{s} \\
& =50 \mathrm{~mm} \times 50 \mathrm{~mm} \\
& =2.500 \mathrm{~mm}^{2}
\end{aligned}
$$

Keterangan:

$\mathrm{A}=$ Luas penampang $\left(\mathrm{mm}^{2}\right)$

$$
\mathrm{s} \quad=\operatorname{sisi}(\mathrm{mm})
$$

Kuat tekan mortar (MPa) umur 7

\begin{tabular}{|c|c|c|c|c|c|c|}
\hline \multirow[t]{2}{*}{$\begin{array}{c}\text { No. } \\
\text { Komposisi }\end{array}$} & \multirow{2}{*}{$\begin{array}{c}\text { Kadar } \\
\text { Mikrosilika } \\
(\%)\end{array}$} & \multirow[t]{2}{*}{$\begin{array}{c}\text { Kadar } \\
\text { Lumpur } \\
(\%)\end{array}$} & \multicolumn{3}{|c|}{$\begin{array}{c}\text { Kuat Tekan } \\
\text { Mortar } \\
(\mathrm{MPa})\end{array}$} & \multirow{2}{*}{$\begin{array}{c}\text { Kuat Tekan } \\
\text { Mortar } \\
(\mathrm{MPa})\end{array}$} \\
\hline & & & 1 & 2 & 3 & \\
\hline 1 & 0 & 0 & 6,60 & 7,00 & 7,20 & 6,93 \\
\hline 2 & 0 & 10 & 6,80 & 6,60 & 7,00 & 6,80 \\
\hline 3 & 5 & 0 & 8,60 & 7,60 & 8,00 & 8,07 \\
\hline 4 & 5 & 10 & 7,60 & 8,00 & 8,60 & 8,07 \\
\hline 5 & 10 & 0 & 7,20 & 8,00 & 7,60 & 7,60 \\
\hline 6 & 10 & 10 & 7,60 & 7,60 & 7,40 & 7,53 \\
\hline 7 & 15 & 0 & 12,00 & 8,00 & 12,00 & 10,67 \\
\hline 8 & 15 & 10 & 8,80 & 12,00 & 11,20 & 10,67 \\
\hline 9 & 20 & 0 & 8,00 & 8,80 & 8,80 & 8,53 \\
\hline 10 & 20 & 10 & 8,80 & 10,00 & 10,00 & 9,60 \\
\hline 11 & 25 & 0 & 10,80 & 8,00 & 8,00 & 8,93 \\
\hline 12 & 25 & 10 & 8,80 & 8,80 & 11,20 & 9,60 \\
\hline 13 & 30 & 0 & 8,80 & 8,00 & 7,20 & 8,00 \\
\hline 14 & 30 & 10 & 8,80 & 8,00 & 8,80 & 8,53 \\
\hline
\end{tabular}
hari diperlihatkan dalam Tabel 5.
Tabel 5. Kuat Tekan Mortar Umur 7 Hari menghitung kuat tekan mortar umur 28 hari. Kuat tekan mortar umur 28 hari dapat dihitung dengan menggunakan rumus:

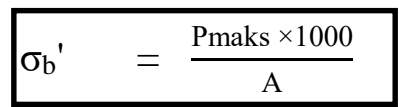

Keterangan:

$\sigma_{\mathrm{b}}{ }^{\prime} \quad=$ Kuat tekan benda uji mortar (MPa)

Pmaks = Gaya tekan maksimum $(\mathrm{kN})$

$\mathrm{A} \quad=$ Luas permukaan benda uji $\operatorname{mortar}\left(\mathrm{mm}^{2}\right)$

Perhitungan luas penampang benda uji mortar:

$$
\begin{aligned}
\mathrm{A} & =\mathrm{s} \times \mathrm{s} \\
& =50 \mathrm{~mm} \times 50 \mathrm{~mm} \\
& =2.500 \mathrm{~mm}^{2}
\end{aligned}
$$

Keterangan:

$$
\begin{array}{ll}
\mathrm{A} & =\text { Luas penampang }\left(\mathrm{mm}^{2}\right) \\
\mathrm{S} & =\operatorname{sisi}(\mathrm{mm})
\end{array}
$$

Kuat tekan mortar (MPa) umur 28 hari diperlihatkan dalam Tabel 6. 
Tabel 6. Kuat Tekan Mortar Umur 28 Hari

\begin{tabular}{|c|c|c|c|c|c|c|}
\hline \multirow{2}{*}{$\begin{array}{c}\text { No. } \\
\text { Komposisi }\end{array}$} & $\begin{array}{c}\text { Kadar } \\
\text { Mikrosilika } \\
(\%)\end{array}$ & \multirow{2}{*}{$\begin{array}{c}\text { Kumpur } \\
(\%)\end{array}$} & \multicolumn{3}{|c|}{$\begin{array}{c}\text { Kuat Tekan } \\
\text { Mortar }\end{array}$} & \multirow{2}{*}{$\begin{array}{c}\text { Kuat Tekan } \\
\text { Mortar } \\
(\text { MPa })\end{array}$} \\
\cline { 4 - 6 } & & & 1 & 2 & 3 & \\
\hline 1 & 0 & 0 & 24,00 & 23,20 & 23,20 & 23,47 \\
\hline 2 & 0 & 10 & 24,80 & 24,00 & 24,00 & 24,27 \\
\hline 3 & 5 & 0 & 28,00 & 24,80 & 26,00 & 26,27 \\
\hline 4 & 5 & 10 & 27,20 & 27,20 & 28,00 & 27,47 \\
\hline 5 & 10 & 0 & 26,00 & 27,20 & 24,80 & 26,00 \\
\hline 6 & 10 & 10 & 28,00 & 24,80 & 24,00 & 25,60 \\
\hline 7 & 15 & 0 & 32,80 & 32,00 & 34,00 & 32,93 \\
\hline 8 & 15 & 10 & 32,00 & 32,80 & 32,80 & 32,53 \\
\hline 9 & 20 & 0 & 28,80 & 30,00 & 28,80 & 29,20 \\
\hline 10 & 20 & 10 & 30,00 & 28,80 & 31,20 & 30,00 \\
\hline 11 & 25 & 0 & 30,00 & 28,80 & 28,00 & 28,93 \\
\hline 12 & 25 & 10 & 28,00 & 28,00 & 30,00 & 28,67 \\
\hline 13 & 30 & 0 & 28,00 & 27,20 & 24,80 & 26,67 \\
\hline 14 & 30 & 10 & 26,00 & 24,80 & 28,00 & 26,27 \\
\hline
\end{tabular}

Berdasarkan perhitungan kuat tekan mortar rata-rata umur 7 hari dan 28 hari didapatkan grafik rata-rata kuat tekan mortar terhadap No. komposisi yang diperlihatkan dalam Gambar 1.

Berdasarkan grafik rata-rata kuat tekan mortar terhadap No. komposisi dalam Gambar 1 didapatkan kuat tekan mortar normal umur 7 hari sebesar 6,933 MPa dan kuat mortar normal umur 28 hari sebesar 23,467 MPa. Kuat tekan mortar optimal umur 7 hari sebesar 10,667 $\mathrm{MPa}$ dan kuat tekan mortar optimal umur 28 hari sebesar 32,933 MPa.

Grafik berikut menunjukan perbandingan rata-rata kuat tekan mortar umur 7 hari dan 28 hari.

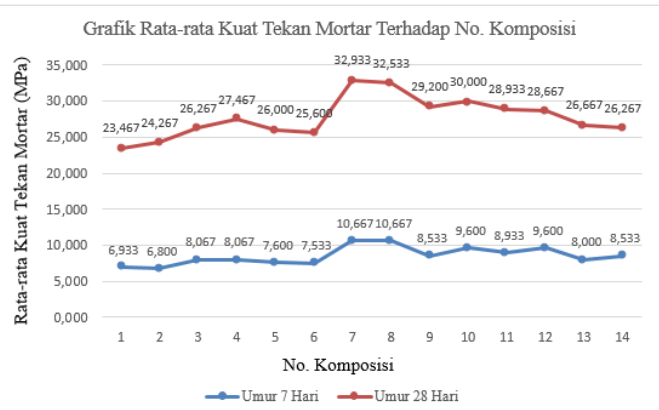

Gambar 1. Grafik Rata-rata Kuat Tekan Mortar Terhadap No. Komposisi

Sehingga didapatkan peningkatan kuat tekan mortar normal umur 7 hari ke 28 hari sebesar $238,483 \%$ dan peningkatan kuat tekan mortar optimal umur 7 hari ke 28 hari sebesar 208,737\%. Peningkatan tersebut diperlihatkan dalam Gambar 2.

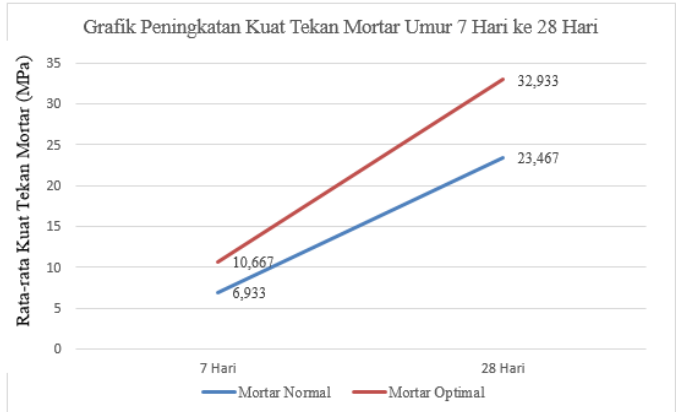

Gambar 2. Grafik Peningkatan Kuat Tekan Mortar Umur 7 Hari ke 28 Hari

\section{PENUTUP}

\subsection{Kesimpulan}

Berdasarkan dari hasil penelitian uji pengaruh proporsi mikrosilika dan kandungan lumpur terhadap kuat tekan mortar dapat disimpulkan sebagai berikut:

a. Kuat tekan optimal mortar umur 7 hari dicapai pada komposisi No.7 dan No.8 yaitu sebesar 10,667 MPa. Komposisi No.7 merupakan mortar dengan penggantian mikrosilika sebesar $15 \%$ tanpa penambahan lumpur. Komposisi No.8 merupakan mortar dengan penggantian $15 \%$ dan penambahan $10 \%$ lumpur. Terjadi peningkatan kuat tekan mortar sebesar $53,846 \%$ dari mortar normal umur 7 hari.

Berikut merupakan hasil penelitianpenelitian sebelumnya yang serupa. Sari dan Amalia (2019) yang melakukan penelitian dengan menambahkan mikrosilika ke dalam semen terhadap nilai kuat tekan beton mutu tinggi dengan kadar 5\%, 10\%, $15 \%$ dan $30 \%$ dari berat semen. Didapatkan kuat tekan beton optimal dicapai pada beton dengan penambahan $15 \%$ mikrosilika pada 
umur 28 hari. Mahyar, Herry (2013), melakukan penelitian dengan menambahkan mikrosilika dalam campuran beton untuk meningkatkan kuat tekan beton normal dengan kadar mikrosilika 0\%, 5\%, 10\%, 15\%, dan $20 \%$. Didapatkan kuat tekan beton optimal dicapai pada beton dengan penambahan $15 \%$ mikrosilika.

Jika dibandingkan, hasil penelitian ini sesuai dengan penelitian-penelitian sebelumnya yang serupa yaitu kuat tekan optimal dicapai pada penambahan atau penggantian mikrosilika sebesar $15 \%$.

b. Pada mortar umur 7 hari, lumpur dalam mortar normal (tanpa penggantian mikrosilika) dapat menurunkan kuat tekan mortar. Akan tetapi, pada mortar dengan penggantian mikrosilika sebesar 20\%, $25 \%$, dan $30 \%$, penambahan lumpur justru tidak menurunkan kuat tekan mortar. Dengan kata lain, terdapat kemungkinan bahwa penggantian mikrosilika dapat mengurangi pengaruh buruk lumpur dalam mortar. Akan tetapi hal ini juga dapat dipengaruhi oleh faktor lain seperti campuran yang kurang homogen atau pemadatan yang kurang baik sehingga hasil yang didapat tidak akurat.

c. Kuat tekan optimal mortar umur 28 hari dicapai pada komposisi No.7 yaitu sebesar 32,933 MPa. Komposisi No.7 merupakan mortar dengan penggantian $15 \%$ mikrosilika tanpa penambahan lumpur. Terjadi peningkatan kuat tekan mortar sebesar $46,522 \%$ dari mortar normal umur 28 hari.

Berikut merupakan hasil penelitianpenelitian sebelumnya yang serupa. Sari dan Amalia (2019) yang melakukan penelitian dengan menambahkan mikrosilika ke dalam semen terhadap nilai kuat tekan beton mutu tinggi dengan kadar 5\%, 10\%, $15 \%$ dan $30 \%$ dari berat semen. Didapatkan kuat tekan beton optimal dicapai pada beton dengan penambahan $15 \%$ mikrosilika pada umur 28 hari. Mahyar, Herry (2013), melakukan penelitian dengan menambahkan mikrosilika dalam campuran beton untuk meningkatkan kuat tekan beton normal dengan kadar mikrosilika 0\%, 5\%, 10\%, 15\%, dan 20\%. Didapatkan kuat tekan beton optimal dicapai pada beton dengan penambahan $15 \%$ mikrosilika.

Jika dibandingkan, hasil penelitian ini sesuai dengan penelitian-penelitian sebelumnya yang serupa yaitu kuat tekan optimal dicapai pada penambahan atau penggantian mikrosilika sebesar $15 \%$.

d. Pada mortar umur 28 hari, lumpur dalam mortar normal (tanpa penggantian mikrosilika) justru tidak menurunkan kuat tekan mortar yang seharusnya menurunkan kuat tekan mortar. Hal ini dapat disebabkan oleh campuran yang kurang homogen atau pemadatan yang kurang baik sehingga hasil yang didapat tidak akurat. Lumpur dalam mortar dengan penggantian mikrosilika sebesar $10 \%$ dan $15 \%$ dapat menurunkan kuat tekan mortar. Akan tetapi, pada mortar dengan penggantian mikrosilika sebesar 5\%, 20\%, 25\%, dan $30 \%$, penambahan lumpur justru tidak menurunkan kuat tekan mortar. Dengan kata lain, terdapat kemungkinan bahwa penggantian mikrosilika dapat mengurangi pengaruh buruk lumpur dalam mortar. Akan tetapi hal ini juga dapat dipengaruhi oleh faktor lain seperti 
campuran yang kurang homogen atau pemadatan yang kurang baik sehingga hasil yang didapat tidak akurat.

\subsection{Saran}

Berdasarkan dari hasil penelitian dan kesimpulan yang telah dijelaskan, maka penulis memberikan saran untuk penelitian selanjutnya agar hasil penelitian dapat dikembangkan dan memperoleh hasil yang lebih optimal. Saran dari penelitian ini adalah sebagai berikut:

a. Untuk penelitian selanjutnya dianjurkan untuk tidak menggunakan agregat halus (pasir) yang terlalu kering. Lebih baik menggunakan pasir dalam kondisi Saturated Surface Dry (SSD) agar air campuran mortar tidak terlalu banyak diserap oleh pasir sehingga air yang dibutuhkan untuk campuran mortar tidak terlalu banyak.

b. Untuk penelitian selanjutnya dianjurkan menggunakan komposisi perbandingan semen : pasir yang lebih beragam, misalnya $1: 3$ dan $1: 5$ sehingga hasil yang didapatkan lebih bervariatif dan dapat dibandingkan satu sama lain.

c. Pada penelitian ini subtitusi atau penggantian mikrosilika adalah $0 \%$, $5 \%, 10 \%, 15 \%, 20 \%, 25 \%$ dan $30 \%$ dari berat pasir. Untuk penelitian selanjutnya, dianjurkan untuk melakukan subtitusi atau penggantian mikrosilika dengan persentase tertentu dari volume pasir.

d. Untuk penelitian selanjutnya sebaiknya menggunakan alat uji kuat tekan (compression testing machine) dengan tingkat ketelitian yang lebih teliti agar hasil uji kuat tekan yang didapatkan lebih akurat.

\section{DAFTAR PUSTAKA}

Asia, N. (2014): Pengaruh Penambahan Natrium Klorida $(\mathrm{NaCl})$ Terhadap Waktu Ikat, Kuat Tekan Mortar dan Pasta, Jurusan Teknik Sipil Fakultas Teknik Universitas Hasanudin. Makassar.

ASTM.C.1240: Pengaruh Penambahan Silica Fume, diperoleh dari situs internet: https://www.slideshare.net. Diunduh pada tanggal 9 Agustus 2020, pukul 13.45 WIB.

Mahyar, H. (2012): Mikrosilika Sebagai Bahan Tambah Untuk Meningkatkan Kuat Tekan Beton Mutu Tinggi, REINTEK, Vol.7, No.1. Malang.

Mahyar, H. (2013): Pemakaian Additive Micro Silica Dalam Campuran Beton Untuk Meningkatkan Kuat Tekan Beton Normal, Jurnal Portal, Vol.5, No.1, Malang.

Sari, A.A.P., Anif, B., dan Mizwar, Z. (2019): Pengaruh Bahan Silica Fume Terhadap Nilai Kuat Tekan Beton Mutu Tinggi, Universitas Bung Hatta. Padang.

SNI 03-6825-2002: Metode Pengujian Kekuatan Tekan Mortar Semen Portland Untuk Pekerjaan Sipil, diperoleh dari situs internet: http://nspkjembatan.pu.go.id/ public/uploads/TahapPelaksanaan/SN I/1510486503(251_lagi)_sni_066825-2002.pdf. Diunduh pada tanggal 2 Agustus 2020, pukul 14.45.

SNI 03-6882-2002: Spesifikasi Mortar Untuk Pekerjaan Pasangan, diperoleh dari situs internet: 
http://eprints.polsri.ac.id/277/9/Lamp iran3.pdf. Diunduh pada tanggal 2 Agustus 2020, pukul 17.55.

Zulfikar, C., dan Priyanto, S. (2019): Tinjauan Ulang Mengenai Kadar Maksimum Lumpur Pasir dalam Campuran Beton Cara SNI, Jurnal Online Institut Teknologi Nasional. Bandung. 